Article

\title{
Making Migrants' Input Invisible: Intersections of Privilege and Otherness From a Multilevel Perspective
}

\author{
Ewa Palenga-Möllenbeck \\ Institute of Sociology, Goethe University Frankfurt, Germany; e.pm@em.uni-frankfurt.de
}

Submitted: 5 August 2021 | Accepted: 18 November 2021 | Published: 22 March 2022

\begin{abstract}
For some years, the German public has been debating the case of migrant workers receiving German benefits for children living abroad, which has been scandalised as a case of "benefit tourism." This points to a failure to recognise a striking imbalance between the output of the German welfare state to migrants and the input it receives from migrant domestic workers. In this article I discuss how this input is being rendered invisible or at least underappreciated by sexist, racist, and classist practices of othering. To illustrate the point, I will use examples from two empirical research projects that looked into how families in Germany outsource various forms of reproductive work to both female and male migrants from Eastern Europe. Drawing on the concept of othering developed in feminist and postcolonial literature and their ideas of how privileges and disadvantages are interconnected, I will put this example into the context of literature on racism, gender, and care work migration. I show how migrant workers fail to live up to the normative standards of work, family life, and gender relations and norms set by a sedentary society. A complex interaction of supposedly "natural" and "objective" differences between "us" and "them" are at work to justify everyday discrimination against migrants and their institutional exclusion. These processes are also reflected in current political and public debates on the commodification and transnationalisation of care.
\end{abstract}

\section{Keywords}

care; discrimination; domestic work; intersectionality; othering; transnational migration

\section{Issue}

This article is part of the issue "Transnational Social Protection: Inclusion for Whom? Theoretical Reflections and Migrant Experiences" edited by Elisabeth Scheibelhofer (University of Vienna), Emma Carmel (University of Bath), and Anna Amelina (University of Cottbus).

(C) 2022 by the author(s); licensee Cogitatio (Lisbon, Portugal). This article is licensed under a Creative Commons Attribution 4.0 International License (CC BY).

\section{Introduction}

The emotive term Sozialtourismus ("benefit tourism") keeps resurfacing in German public discourse. One such occasion was in 2016, when the debate focused on transnational migrant workers from Central and Eastern Europe (CEE) - they were accused of exploiting a supposed loophole in the German child benefit scheme by receiving German child benefits for their children, who were living in their respective countries of origin. This notion is not only questionable from a theory of justice perspective, but it is also factually wrong, insofar as it ignores the nature and amount of work done by large numbers of CEE migrants in Germany. This in turn means that the German public fails to perceive a strik- ing imbalance between the output of the German welfare state directed to migrants and the input it receives from migrant domestic workers. In this article, I seek to show how processes of othering along sexist, racist, and classist lines obfuscate the migrants' contributions and render them invisible, thus legitimising discrimination in everyday interactions and exclusionary practices on the part of institutions.

For this purpose, I will use examples from two empirical research projects that investigated how Germansboth parents and adult children of dependent parents"outsource" reproductive work to both female and male domestic migrants from CEE. Drawing on the concept of "othering" developed in feminist and postcolonial contexts, I will apply it to the context of German political 
discourse to understand how ideals like gender equality or fair work conditions paradoxically produce a new international division of domestic and care work that is anything but gender-equal or fair.

The accusation directed against migrant workers is based on the fact that many of them fail to live up to normative standards of work, family life, and gender relations and norms set by the sedentary mainstream. I will show how such perceived differences between "us" and "them" are then instrumentalized to legitimize everyday discriminations and institutional exclusion.

The notion of "benefits tourism" implies that migrants from CEE are coming with the intention of "enjoying themselves" at the expense of the locals. On an ethical level, this notion has been criticized as xenophobic and classist. In this article, however, I try to show that it must be criticized also on a factual level, as it distorts the actual situation by rendering invisible one side of an implicit social contract between the receiving society and the migrants, to the point of being paradoxical. For instance, Polish migrants are the largest national group of child benefit recipients from within the EU in Germany, and more than half of them receive those benefits for children living in Poland: 87,000 Polish children account for more than half of all cases in which child benefits are paid for children outside Germany. This fact is often scandalised in the media, but what is ignored is that Poles are also by far the largest group of new migrants coming to Germany from within the EU. More importantly, however, it also ignores that for at least the last 25 years, they have also comprised the largest portion of domestic workers-elder carers, cleaners, and handymen - who are often employed informally.

\section{Data and Methods}

The first case involves men from CEE who work in the construction sector or in private households as "handymen," a phenomenon that has only recently begun to be researched (Kilkey \& Perrons, 2010). While reproductive work is traditionally seen as stereotypically "female," there is a male side to it: Applying a broader definition, maintenance tasks around the house, like renovations, repairs, gardening, are also "reproductive," but are typically done by men. At this point, they are often "outsourced" to male Polish migrants in Germany. The project Men in Global Care Chains was conducted from 2012-2013 and combined three methods: a secondary analysis of regional statistics on handyman activities on the labour market; an analysis of "brokering firms" and internet forums used by handymen and households; and 37 in-depth interviews with Polish handymen, their partners, informal brokers and companies in the handyman sector, and men and women in households with dependent children employing Polish handymen.

The second project, Decent Care Work (2017-2021), focused on so-called 24/7 live-in elderly care. The activities of transnational agencies brokering migrant care work in Germany were examined from the perspective of the agencies, stakeholders, workers, and care recipients and their families. The study combined four methods: document analysis (regimes of labour market, migration, gender, and care); analysis of websites of transnational care agencies (of which 140 were based in Poland and 337 were based in Germany); interviews (42 semistructured and expert interviews with six agencies based in Poland and 11 agencies based in Germany); interviews with two employer-oriented organisations in Poland, plus three employer- and two employee-oriented organisations or counselling centres in Germany; interviews with 10 migrant care workers, four of their family members, three relatives of care recipients.

During data collection and analysis, the principles of grounded theory were applied (Glaser \& Strauss, 1980). Framed in terms of standpoint epistemology, my position as a Polish-German researcher who worked as a caregiver for the elderly and severely disabled for several years means that I had linguistic and cultural competencies that enabled me to adopt both an external and an internal perspective. This had a profound impact on the research process, starting with the choice of research interest, the selection of literature, the communication with interviewees, and the interpretation of the data. In particular, all interviews were conducted in the participants' native language to mitigate power asymmetry. The Decent Care Work project was carried out by a multilingual team in which I conducted several interviews in Polish; I also conducted all interviews in the "handymen" project. Of course, communicating in the participants' own language cannot completely remove power asymmetry and biases from the research process. Biases created by differences in class, age, ethnicity, or gender remain and need to be reflected upon as part of the research process. Similarly, the use of a common language can create the pitfall that researchers overestimate their "insider knowledge." To address these risks, the interpretation was discussed in group contexts as far as possible.

\section{Theoretical Considerations: Racism Without Races, Paradoxes of Gender Equality, and the Redistribution of Family Work in Germany}

The starting point of my theoretical reflections is my longterm observation of the field. Even though there is by now an extensive body of research on the disadvantaging of domestic workers from CEE in Germany-such as structural discrimination in the labour market or in workers' everyday relations with their clients-this form of employment has become increasingly common. More recently, it has even been legitimised as a "fair" contract, as a win-win situation for all involved parties, both by clients and agencies, and even by the workers themselves (Aulenbacher et al., 2021).

From research on the denial of discrimination by discriminators, we know that this primarily serves to 
preserve their own privileges. The existing body of intersectionally-oriented research on migrant domestic work has already thoroughly analysed the complex positioning of CEE migrant workers (Karakayali, 2010; Lutz, 2008): It has clearly shown that their gender, class, age, and ethnicity do represent disadvantages as well as resources. In this intersectional tradition, however, I would like to limit myself in this article to explain the salient tendency of how evident disadvantages are systematically legitimised, even glossed over, by those who benefit from them. Among others, postcolonial and feminist othering concepts can explain the connection between the disadvantages of the minority and the privileges of the majority; these will be used here in conjunction with other concepts, such as citizenship as a "community of values," following Anderson (2013), or mechanisms of (institutional) discrimination (Gomolla, 2010).

A key tenet of feminist theory is that a set of pervasive androcentric norms in society disadvantage women and privilege men, for which Connell (2005) coined the term "patriarchal dividend." Such privileges are the subject of feminist literature on intersectionality, e.g., in black feminism (Collins, 2008; Yuval-Davis, 2006) and critical whiteness studies (Mclntosh, 1997). Feminist theory explains the invisibility and undervaluation of reproductive work from a socio-theoretical (Becker-Schmidt, 2004; Federici, 2015) and constructivist perspective. The differentiation and naturalisation of a binary gender order is seen as a central mode of producing social inequalities. Especially with the approach of "doing gender while doing work," the gendered hierarchy of household work could be analysed (Gottschall, 1998). In contrast, the increasing degree of organisation of live-in elderly care or handymen work is a relatively new empirical phenomenon. In the European (as opposed to the Northern American or Asian) context (Chang, 2018; Ortiga et al., 2021), there are few studies on the subject overall (Krawietz, 2014; Leiber et al., 2019) and even fewer gender-theoretical analyses (Kilkey et al., 2013). To illustrate my argument, I will therefore draw on approaches in the sociology of professions dealing with gendered differentiation in professional hierarchies, which are used in a continuum between informal attributions of competence and formal hiring criteria to achieve higher profits, among other things (Wetterer, 2017).

From an intersectional perspective, ethnicity is considered a category to be deconstructed. Postcolonial and racism studies, on the other hand, have so far found less application in the study of ethnicity in Germany, for a range of reasons. For one thing, the concept of racism itself is treated with some scepticism in Germany, unlike in the English-speaking world. As the concept of "race" is primarily associated with the period of National Socialism, Germany's reckoning with its colonial history is still in its infancy, and most labour migrants arriving in Germany are from "white" backgrounds, the concept of "ethnicity" is used more commonly in the German sociology of migration. What is commonly called "racism" in English-speaking publications is more likely to be referred to as "xenophobia" (Fremdenfeindlichkeit) or "hostility towards foreigners" (Ausländerfeindlichkeit). At the same time, newer types of racism, such as cultural racism or Islamophobia, have also been debated in Germany for some time. Postcolonial studies and critical race theory are also less often applied to CEE migrant workers because their countries of origin are not typical colonies or not colonies at all, and Eastern Europeans, predominantly, are "white." In the literature on migration, Polish immigrants in particular have for a long time been labelled as an "invisible" minority because they are considered as "inconspicuous" and "well integrated."

Terkessidis (2019) interprets this invisibility from a postcolonial perspective: for him, pressure to assimilate into German society is one reason why the postcolonial memory of Polish migrants is absent in Germany. He also considers German-Polish history a part of European colonial history, against which background the pejorative expression polnische Wirtschaft ("Polish economy," a synonym for mismanagement) continues to exist in the German language today. Thus, postcolonial perspectives on European history are gaining momentum and the role of Germany-not only as a target of immigration but specifically as a former imperial power-is analysed in this context. To be accurate, from the Polish perspective, this discussion has been going on for some time but has been less focused on the role of the West. Rather, the Polish discourse presents a complex mélange in which Poland appears as both colonised (by Germany, Russia, and "the West") and colonising (in relation to its former Eastern borderlands). Zarycki (2014, pp. 89-114) examines in detail the problems of translating the concept of postcolonialism into a Polish context; Mayblin et al. (2016) provide a recent example of its application to biographical research. The postcolonial perspective seems particularly fruitful in the context of the current discussion about a "post-migrant" society (Huxel et al., 2020). Most importantly, the CEE domestic workers, such as the stereotypical "benefits tourist" mentioned previously, can be understood from a postcolonial perspective as the epitome of the poor, backward migrant from a past world who functions as an antithesis to "ourselves," with "our" modern values and lifestyles.

In this context, I adopt the term "postcolonial" in a broader sense than usual, going beyond the binary classification of white vs. non-white societies that is often associated with it. In migration studies, Eastern Europeans are generally labelled as "white" in this binary classification, even if they are often placed at a relatively low position in the stratified social order. As Safuta (2018) shows with the example of Ukrainian domestic workers in Poland and Polish domestic workers in Belgium, they occupy a position that is best understood as one of (in Wallenstein's sense) "peripheral" whiteness. In this sense, she applies the concept of a "racial contract" - a term Mills (1997) coined to describe the division of labour between people of different racial 
backgrounds in North America-to the European case: Here, a similar hierarchy exists, but with people of different "shades of white" (Safuta, 2018) placed along with it.

The "racial contract" between CEE migrants in domestic work and their clients assigns to them what Safuta (2018) describes as a "comfortable alterity." They are paradoxically privileged because, like their clients, their skin colour is (a shade of) white and (compared to migrants from the Global South) they share a similar cultural or religious background with their clients. At the same time, they are not accepted as equal by their clients but are considered subordinates due to their "peripheral" whiteness (Amelina \& Vasilache, 2014). In domestic work settings, this combination of subordination and similarity is strengthened further by the particular kind of emotional labour they perform (Safuta, 2018).

Alongside cultural and gendered differences, class is another factor that functions to mark proximity and distance, or the distinction between "one's own" and "the foreign"; othering based on poverty is another element constituting racism without races (Anderson, 2013). The mere existence of poverty is perceived as a threat to the social order and the meritocratic principle with its naturalisation of personal achievement, which forms a defining principle of modern society. CEE migrants, like migrants in general, tend to work in economic sectors that have been come to be recognised as "systemically relevant" since the Coronavirus pandemic but are particularly affected by precarious employment (Khalil et al., 2020). In addition, especially in the area of reproductive work, workers are being systematically deprived of their citizenship rights (Plomien \& Schwartz, 2020).

Although we are talking about EU nationals, who are legally privileged in comparison with non-EU nationals, we can observe that their citizenship rights, in particular social rights, are "eroding" even while they are "expanding" in other respects (Kivisto \& Faist, 2007). This development is causing increasing structural disparities within the EU. Amelina et al. (2020) and Engbersen et al. (2017) also show how the de jure and de facto rights of EU citizens diverge. However, this structural situation is often individualised (Kordasiewicz, 2016) and sometimes racialised. This shows that class-based discrimination (classism) may become overtly evident when individuals experience discrimination based on their social background or lifestyle, or covertly evident, in the guise of racism and sexism. The nexus of classism and racism has been pioneeringly explored by black feminists in the USA; the discourse gained momentum after Crenshaw (1989) coined the concept of intersectionality (Kemper, 2016).

As Barone (1999) argued, compared with racism and sexism, classism has long been a neglected topic of research on discrimination even while it forms a central category in research on labour migration, e.g., when discussing the precarity of work and the devaluation of skills (Kofman \& Raghuram, 2015). In studies on migrant domestic workers, class-based othering is analysed primarily at the level of relations between individuals (domestic workers and clients). One example for this type of othering has been observed by Kordasiewicz (2016) in her study on domestic workers in post-war Poland: Class relations are often disguised by individualising them, e.g., when the domestic worker's subordinate position is justified by references to deviations in their biographies (such as alcohol abuse).

In comparison to this type of discrimination in relationships between individuals, institutional discrimination remains less researched (Bomert, 2020). Consequently, this article also aims to stimulate the debate on transnational care work and social memberships from an intersectional, discrimination-critical, multi-level perspective.

\section{Domestic Workers From Poland: Intersections of Otherness and Privilege From the Multilevel Perspective of Individual Actors and Organisations}

Both case studies mentioned above deal with care work that is increasingly commodified, i.e., is no longer provided for free within the family, but is brought in from outside. Specifically, care work is "bought in" from CEE migrant women, who in this way help German families of the upper-middle class to cope with their everyday lives and to reconcile the demands of work and family. These migrants are thus seen as informal welfare givers in their host societies (Kofman \& Raghuram, 2015).

\subsection{Othering and Privilege in Everyday Relations: Clients and Workers in Private Households}

Along with house cleaning, care work is the prototypical example of reproductive work that is predominantly done by women. However, work that is usually done by men, such as renovations, repairs, gardening, etc., can also be considered a part of reproductive work. In private households, this type of work is also increasingly performed by CEE migrants. The motivation to delegate this work to others is well-illustrated by the following statement from a client (Stefan) in an interview I conducted:

My wife and I, we are both working, we're not really into cleaning the house, doing repairs, and stuff. That's why we're hiring someone to do it, so we have more free time...and we have to look after our son. He's 15 now, so he still needs a lot of support and attention after all.

Stefan frankly declares that he and his wife are simply "not interested" in housework. Here the core of this contract is revealed: The outsourcing of domestic work (both "male" and "female") is what makes egalitarian gender relations and modern praxes of motherhood and fatherhood possible in the first place. The individual life situations of the people who perform these services are not 
perceived as relevant in this context; it simply remains outside of Stefan's perception. The subtle way in which inequalities are concealed in the characteristics of the handyman job and how they are legitimised by the narrative of supporting disadvantaged migrants becomes evident in the following statements from an interview with a handyman and his client. For twelve years, 52-year-old Thomas has been outsourcing various chores around his house and garden to 61-year-old Polish migrant Zygmunt. Both men describe their relationship as one of friendship and mutual trust. Thomas describes it as based on "reciprocal" benefits and frames his part as helping Zygmunt without seeking any benefit for himself:

Thomas: Well....I pay Zygmunt 10 euro an hour and I think it's...quite inexpensive, but that's also the reason why I'm having him do all these things, which perhaps I wouldn't have otherwise. For example, during a time when Zygmunt was out of work, he was doing all kinds of things, I had a lot of money, relatively speaking, I had taken a credit for the renovation, and then he was really working here for hours on end.

Interviewer: So it was a deal, in your eyes, that you supported him?

Thomas: It was perfectly okay, I wouldn't have been able to do it at all if I'd had little money, well, so it simply all fell together, it was just the right thing at the time, and insofar it was okay, [I said] just go ahead.

Here we observe how Thomas subtly justifies his unequal relationship with Zygmunt-he tries to frame it in the broad terms of friendship and emphasises their ostensibly egalitarian win-win situation. What remains outside this view is Zygmunt's situation as a husband and father of three children. Unlike his client-friend, who spends his free time with his little son, Zygmunt has been spending all his time off on various other jobs to achieve what he considers an acceptable standard of living for himself and his family (Palenga-Möllenbeck, 2016).

This ignorance or invisibility is made possible by processes of othering, which justify inequality and disguise one's own privilege. Anderson (2013) analyses how such processes of inclusion and exclusion on the individual level can be transferred to the level of political discourse on the example of UK migration policy. She describes how modern states do not see themselves simply as communities of individuals with equal codified rights, but as "communities of values" made up of people committed to unwritten common ideals and patterns of behaviour considered honourable (Anderson, 2013). Anderson describes the "us and them" contrast between good citizens, who share these values, non-citizens, who do not share these values and have "wrong" values instead, and failed citizens, who have proved unable to live up to the shared values and thus become "internal strangers." The narratives on CEE migrants found in nearly all interviews with clients (and institutional actors) are likewise rooted in a differentiation between "them" and "us," and can also be described using Anderson's terms. Even perceptions that see the employment of migrant caregivers from less affluent countries as a win-win situation, are largely based on acts of othering that attach certain labels to them that mark "them" as inferior to "us." These labels are "sticking" (Ahmed, 2014) to the entire group, even when they are welcomed as useful. Ironically condensed, this othering works as follows: "We" are in a care crisis, "our" welfare state is under pressure, "we" have perfectly good reasons to act the way we do-we are even doing "them" a favour by allowing them to work for less than the minimum wage. "They" should be grateful for being given the chance to earn some money for their children's education-and isn't everything so cheap over there, anyway?

Such narratives conveniently overlook the fact that "our" lifestyle would not be feasible without the services provided by those migrants. As postcolonial and feminist authors have pointed out, "we" tend not to see the structural causes and the direct connection between our privileged situation and "their" underprivileged one. Instead, "we" actively essentialise, naturalise, or culturalise "them" in a way that allows us to think of ourselves as "better." This phenomenon may best be illustrated by how "we" judge the way that "they" treat their children: "We" spend quality time with ours in the evenings or on weekends, "they" leave their neglected children behind in Poland-and since they incorrigibly "are" that way, they may as well look after our old parents, or fix some things around the house for us (Palenga-Möllenbeck, 2016).

\subsection{Institutional Othering and Privilege: Elderly Care Placement Agencies}

The legitimation of inequality based on othering and the win-win argument is not only found in the narratives of the buyers of domestic services. In contrast to the less formal relationships described in the example above, the example of the live-in elderly carers shows how othering works in institutional terms.

As in the case of Polish handymen, care work performed by women has been a constant element of transnational migration between Poland and Germany in the era after 1989. While this kind of work was initially arranged mostly by informal intermediaries, the last ten years have seen a rapid growth of transnationally-operating agencies formally mediating employment (Aulenbacher et al., 2021; Krawietz, 2014; Leiber et al., 2019).

As our analysis shows, the practices of othering in the everyday business practices of these intermediaries combine the traditional elements of racism, sexism, and classism (such as naturalisation/culturalisation and the adoption of implicit norms modelled on the mainstream values of the receiving society). These, in turn, 
smoothly transition into forms of othering described in more recent discussions, such as neo-liberal instrumentalisation in the case of "femonationalism" (Farris, 2017), or health sector-specific professional discourses of rationalisation in which the progressive monetisation of care work results in specific divisions of labour and profit between professions, networks, ethnicities, and mobile workers (Aulenbacher et al., 2018).

At the centre of the analysis is the collective othering that takes place within the industry as expressed in its concepts and practices, in particular the recruitment of workers and the work itself. As will be shown, these are based on a sexist, racist, and class-based construction of homogeneous groups of workers. Thus, in these transnational labour markets (Shire, 2020), we see both direct and legal (through explicitly exclusionary norms and practices) and indirect (through apparently neutral norms and practices) effects of de-professionalisation and an erosion of labour rights. Although these can be observed in the entire elderly care sector (Dammayr, 2019), in this case they are reinforced by the ethnicisation and transnationalisation of the labour market segment and a shifting of risks from the West to the East within subcontracting structures that is typical for transnational labour markets (Mense-Petermann, 2020).

This process of constant differentiation, combined with hierarchisation, and the emergence of exclusions for some and the consequent privileges for others, as well as their functions and legitimisation, will be shown in the example of three areas in which we traditionally find indicators of what the ILO calls "good work," and by means of which the industry permanently places workers outside the framework of (a) professionalisation, (b) remuneration, and (c) regulation of work, especially as far as the issues of responsibility and risk are concerned.

When advertising its services, the industry uses a narrative of legality about the (largely informal) market. It emphasises that in recent years the industry has been increasingly formalised and the work itself has undergone a certain professionalisation. So let us take a closer look at the social construction of this work in the context of the professionalisation of the work and the required skills, which Chun (2009) calls the "classification struggle" in the context of the struggle for good work.

The agencies mostly use the term "care" (Pflege, pielęgnacja) in a rather unspecific way, even though both in Poland and Germany profession-related regulations exist that determine its meaning. Recently, a DIN (2021, p. 1) specification on "caregiving...through live-in caregivers from foreign countries" detailing "requirements for brokers, service providers and caregivers" was developed with limited involvement of stakeholders. However, its provisions are rarely explicitly referred to in the recruitment and contracting process, or in actual practice. Instead, an informal understanding of care skills is underlying, which women are somehow supposed to be particularly capable of "by nature" and/or have learned in their own families. Accordingly, care experience from one's own family is one of the few hard criteria in the recruitment process.

In this context, it is worth mentioning that even in the discourse on professional care work, the type of work is often considered not entirely formalisable because of its special characteristics. Helping people in need is seen as a moral duty as opposed to a professional task; the relationship with the person in need of care is seen as holistic and individual as opposed to business-like (Waerness, 1984). Such a differentiation and hierarchisation of qualifications between professions and horizontally within professions themselves have already been well described in the literature on gender functions in professions (e.g., Gottschall, 2010) and organisations (Wetterer, 2017): It leads to a privilege for men, which we also observe in our research.

In addition, we find here a social construction of skills attributed to a specific group of foreigners, in particular women from CEE, who are supposed to be predisposed to this work due to their cultural proximity (cuisine, mentality) and religious proximity (Catholic socialisation, predisposition to care). One representative of an employers' organisation self-ironically but bluntly evokes the (auto-)stereotypes that supposedly justify an international division of labour, in which Polish women take over subservient work that is "unworthy" of Germans:

People who have grown up here in Germany...are used to the German way of life, so to speak....You'll hardly manage to convince them to live and work with someone in a domestic community. That is beneath the dignity of a German. A German...places great value on...not having to serve....That's not really in our nature and, yes, that's what I need to do when I live in a domestic community. (Organisation 1)

This implied superiority of German workers/citizens contrasts with the notion that the migrants are grateful for the opportunity to escape from their own "defective" families by working in Germany, which appears in the following statement by an industry representative:

You don't have a proper education...maybe with the Poles it's often like, your husband is an alcoholic, you don't feel like staying at home and getting beaten up anyway...and then you go to Germany and earn really good money in these short periods of time. (Organisation 2)

We observe here even stronger tendencies towards a racialisation or culturalisation of social conditions: a similar trope of justification as in the phenomenon of "white men...saving brown women from brown men" described by Spivak (1988, p. 296). At the same time, another group of failed citizens (Anderson, 2013) is constructed as a contrast in a rather classist and disparaging way in order to strengthen the stereotypical positive image of CEE women as "hands-on": 
As a rule, Germans are not flexible enough and the [German welfare recipients] are not necessarily people who are prepared to do strenuous work on a continuous and reliable basis. (Organisation 2)

Thus, in this gendered and ethnically segregated sector of work, which in Germany (and in Poland) has traditionally been and still is unpaid and informal work, there is a tendency towards deskilling, which has been widely described in the literature and by female migrants, because the transferability of skills is limited in such sectors (Dobranja, 2017).

This deskilling is not only part of the everyday business practice in which supposedly "natural" female or ethnic skills are sold in place of professional qualifications, which results in the workers being socially marginalised. It is also taking place on the institutional level of the transnational secondary labour market in the German welfare market (Ledoux et al., 2021). This sector is already complementary to the formally qualified and better-paid elder care sector, but, as our research has shown, the sector is also striving to be fully integrated into the formal care system that is financed by statutory health insurance.

Salient here is the already mentioned effect of hierarchisation along with the emergence of a new, ethnicallydefined underclass. This means that local employees are already enjoying privileges now. In future, it will also give German agencies, which are already lobbying to achieve favourable regulation (as in the case of the DIN specification mentioned above), an even greater influence on the valuation and sale of care work. The industry plays an important institutional role here (Aulenbacher et al., 2021; Leiber et al., 2019) and is now becoming an important player in the social construction of "ideal" care workers in transnational care chains. This applies to both the hierarchical elderly care skill regimes of the receiving countries and the recruitment and qualification processes in sending countries (Ortiga et al., 2021).

The second discriminatory practice is the underpayment of workers, which is accompanied by a rhetoric of "fair pay." The low pay is due to the low qualifications described above, but it is also specific typical for live-in work, where working hours are practically unregulated (hence the moniker "24-hour care") and conditions are severe (social isolation, lack of privacy, etc.). Considering that the wage ratio between Poland and Germany is currently $1: 3$ and the lack of a strong welfare state in Poland, earnings of $€ 1,000$ to $€ 1,800$ per month are indeed high from a transnational perspective. Labour migration in and of itself remains an important option for the workers, who for the most part consciously choose this form of earning in the context of their individual lives.

However, what is interesting for us here is how these non-standard working conditions and wages are legitimised. The sector uses a win-win rhetoric and bases this on a notion of "justice" that supposedly considers the specific needs and abilities of CEE workers, but also the "innate" willingness to help. This narrative is a part of what from a postcolonial perspective can be described as an imperialist encroachment of the West on the human and symbolic resources of the East for its own advantage.

The owner of Agency 2 frames the activity of his business as a kind of development aid:

So the idea of our business model from my point of view is that we are talking about the principles of fair care [work], that we want to provide an honest and fair value for what we charge....and for people who come from an even more difficult situation we simply provide even more...don't we?

Finally, let us look at the discriminatory effects caused by the specific way these transnational labour markets segments are regulated (Shire, 2020).

First, to a large extent, the markets have produced a business model which transfers risks and responsibilities "downstream" along value chains (Palenga-Möllenbeck, 2021). In the EU, this often involves the outsourcing of labour and responsibilities to subcontractors who send posted workers to another member state (Mense-Petermann, 2020).

Second, the organisations operating in these markets apply an ostensibly neutral procedure, which however is androcentric, ethnocentric, and classist in itself, and thus has a discriminatory effect on those who do not conform to these norms. Being EU citizens with extensive labour and social rights, these workers appear privileged in comparison to undocumented workers. However, in this industry, they can only work as self-employed; the business rests on two legal models, in both of which responsibility for working conditions is largely or entirely transferred to the workers.

If they are self-employed, they work as contractual parties and bear the full entrepreneurial risk. They are conceived of as typical rational-choice actors who have access to full information and capital. This fits in with the current neo-liberal vision of work with minimal employee rights and in which the employees disavow themselves of all responsibility. In particular, "foreigners" such as transnational migrants are virtually guest workers, who are de jure or de facto excluded from many social privileges (Engbersen et al., 2017).

In the second, thus-far dominant model, the postedworker system, workers are employed through contracts not covered by labour law in the sending country. Here, too, the central characteristic is a shifting of responsibility (for training, managing day-to-day work, mediating conflicts, etc.), this time literally across borders, along transnational commodity chains, which are themselves asymmetrical (Palenga-Möllenbeck, 2021).

The literature on institutional discrimination often observes the danger of questions of equality and justice being depoliticised by their being reduced to the level of organisations and relevant technical procedures (Gomolla, 2010). However, it is above all the structural 
past-in-present discrimination that a society inherits from its history (Feagin \& Feagin, 1986) and current discourses about supposed "others," e.g., in labour markets, that guarantee that the distinctions between "us" and the "others" are consistently reproduced, as the scandalisation of "benefit tourism" demonstrates.

\section{Conclusions}

Discourses such as that on "benefit tourism" are based on a distorted perception of reality. They rest on simple dichotomies between "us" and "them" that help to produce invisible privileges for one side and exclusion for the other side of an implicit contract. The concept of othering is applied to capture this specific combination of disadvantages and privileges. In an intersectional perspective on processes of othering, discriminatory and privileging consequences of sexism, racism, and classism were discussed on the basis of feminist, postcolonial, and classism-related theories. Drawing on two case studies dealing with Polish handymen in German households and transnational agencies placing Eastern European live-in elder carers in German households, intersectional othering was analysed from a multilevel perspective comprising individual actors and organisations. This othering, i.e., the creation of the "them" side, does not only take place in asymmetrical everyday relations between workers and clients: It is also woven in the fabric of increasingly formalising and professionalising transnational labour markets, which is demonstrated by the example of the elderly care employment sector. The agencies mostly base their business on the othering of workers, the naturalisation and culturalisation of their skills and work, a win-win rhetoric that openly rests on a market-liberal world view, or under the guise of "helping," ignorance caused by their own "problems" and washing their hands of practical and moral responsibility on the other side of the border.

Thus, we observe, on the one hand, an unequal treatment of equals (EU citizens) and, at the same time, equal treatment of those who are in fact unequal, as they are particularly vulnerable (Skrivankova, 2010). The construction of the mobile, "self-employed" migrant apparently "without family ties" benefits the employers, placement agencies, and the receiving welfare state. Circular migration is an economical asset, which is also manifested in the idea of the free movement of workers and services legally anchored in EU policies.

Thus, domestic workers in Germany occupy an ambiguous position within German society: Their mobility makes them attractive within the market, but at the same time this very mobility also makes them suspicious or "strange" and restricts their ability to fulfil the expectations that the "community of value" (Anderson, 2013), imposed by the non-mobile and more affluent part of society, has towards "good citizens." All this leads to an overlooked disparity between the contributions that migrant domestic workers and their families are making to the stabilisation of the German welfare state and the benefits they themselves receive from it.

The narratives on alien "benefit cheats" and "bad parents," or on "good" and "bad" carers, is the tip of an iceberg of structural discrimination and instances of othering, which all contribute to the obfuscation of the fact that a privileged "modern" and supposedly equal and autonomous lifestyle is increasingly dependent on the contributions of supposedly archaic and traditional migrants.

\section{Acknowledgments}

I would like to thank my colleagues in the Men in Global Care Chains (Helma Lutz and Paulina Talar) and the Decent Care Work projects (Helma Lutz, Aranka Benazha, Iga Obrocka, Brigitte Aulenbacher, Veronika Prieler, Michael Leiblfinger, Karin Schwiter, Jennifer Steiner, Anahi Villalba) for the insightful discussions we had and their valuable suggestions. Neither project would have been possible without external funding, which was provided by the Hessian Ministry for Science and Art (Men in Global Care Chains) and the German Research Foundation (Decent Care Work). I am also grateful to all interviewees for sharing their stories and knowledge with us, and to the anonymous reviewers for their helpful comments.

\section{Conflict of Interests}

The author declares no conflict of interests.

\section{References}

Ahmed, S. (2014). The cultural politics of emotion (2nd ed.). Edinburgh University Press.

Amelina, A., Carmel, E., Runfors, A., \& Scheibelhofer, E. (Eds.). (2020). Boundaries of European social citizenship: EU citizens' transnational social security in regulations, discourses and experiences. Routledge.

Amelina, A., \& Vasilache, A. (2014). The shadows of enlargement: Theorizing mobility and inequality in a changing europe. Migration Letters, 11(2), 109-124.

Anderson, B. (2013). Us and them? The dangerous politics of immigration control. Oxford University Press.

Aulenbacher, B., Dammayr, M., \& Riegraf, B. (2018). Care und Care Work [Care and care work]. In F. Böhle, G. G. Voß, \& G. Wachtler (Eds.), Handbuch Arbeitssoziologie [Handbook of the sociology of work] (pp. 747-766). Springer.

Aulenbacher, B., Lutz, H., \& Schwiter, K. (2021). Gute Sorge ohne gute Arbeit? Live-in-Care in Deutschland, Österreich und der Schweiz [Good care without good work? Live-in care in Germany, Austria, and Switzerland]. Beltz Juventa.

Barone, C. (1999). Bringing classism into the race \& gender picture. Race, Gender \& Class, 6(3), 5-32.

Becker-Schmidt, R. (2004). Doppelte Vergesellschaftung 
von Frauen. Divergenzen und Brückenschläge zwischen Privat- und Erwerbsleben [The double societalisation of women: Divergences and bridges between private and professional life]. In R. Becker \& B. Kortendiek (Eds.), Handbuch Frauen- und Geschlechterforschung [Handbook of women's and gender studies] (pp. 62-71). Springer.

Bomert, C. (2020). Transnationale Care-Arbeiterinnen in der 24-Stunden-Betreuung: Zwischen öffentlicher (un-)Sichtbarkeit und Institutioneller (de-)Adressierung [Transnational female care workers in 24-hour care: Between public (in-)visibility and institutional (de-)addressing]. Springer.

Chang, A. S. (2018). Producing the self-regulating subject: Liberal protection in Indonesia's migration infrastructure. Pacific Affairs, 91(4), 695-716.

Chun, J. J. (2009). Legal liminality: The gender and labour politics of organising South Korea's irregular workforce. Third World Quarterly, 30(3), 535-550.

Collins, P. H. (2008). Black feminist thought: Knowledge, consciousness, and the politics of empowerment (2nd ed.). Routledge.

Connell, R. W. (2005). Masculinities (2nd ed.). University of California Press.

Crenshaw, K. (1989). Demarginalizing the intersection of race and sex: A Black feminist critique of antidiscrimination doctrine, feminist theory and antiracist politics. The University of Chicago Legal Forum, 140, 139-167.

Dammayr, M. (2019). Legitime Leistungspolitiken? Leistung, Gerechtigkeit und Kritik in der Altenpflege [Legitimate policies of performance? Performance, justice and criticism in elder care]. Beltz Juventa.

DIN. (2021). DIN SPEC 33454:2021-02: Caregiving for people in need of support through live-in caregivers from foreign countries-Requirements for brokers, service providers and caregivers. Beuth.

Dobranja, D. (2017). Global care chains, refugee crisis, and deskilling of workers. Exploring Economics. https://www.exploring-economics.org/de/ entdecken/global-care-chains-deskilling

Engbersen, G., Leerkes, A., Scholten, P., \& Snel, E. (2017). The intra-EU mobility regime: Differentiation, stratification and contradictions. Migration Studies, 5(3), 337-355.

Farris, S. R. (2017). In the name of women's rights: The rise of femonationalism. Duke University Press.

Feagin, J. R., \& Feagin, C. B. (1986). Discrimination American style: Institutional racism and sexism. Krieger.

Federici, S. (2015). Aufstand aus der Küche. Reproduktionsarbeit im globalen Kapitalismus und die unvollendete feministische Revolution [Rebelling from the kitchen: Reproductive labour in global capitalism and the unfinished feminist revolution] (2nd ed.). Edition Assemblage.

Glaser, B. G., \& Strauss, A. L. (1980). The discovery of grounded theory: Strategies for qualitative research (11th ed.). Aldine.
Gomolla, M. (2010). Institutionelle Diskriminierung. Neue Zugänge zu einem alten Problem [Institutional discrimination. New approaches to an old problem]. In U. Hormel \& A. Scherr (Eds.), Diskriminierung. Grundlagen und Forschungsergebnisse [Discrimination. Fundamentals and research results] (pp. 61-93). Springer.

Gottschall, K. (1998). Doing gender while doing work? Erkenntnispotentiale konstruktivistischer Perspektiven für eine Analyse des Zusammenhangs von Arbeitsmarkt, Beruf und Geschlecht [Doing gender while doing work? Epistemic potentials of constructivist perspectives for an analysis of the relationship between labour market, occupation and gender]. In B. Geissler, F. Maier, \& B. Pfau-Effinger (Eds.), FrauenArbeitsMarkt: Der Beitrag der Frauenforschung zur sozio-ökonomischen Theorieentwicklung [Women's labour market: The contribution of women's studies to the development of socio-economic theory] (pp. 63-94). Edition Sigma.

Gottschall, K. (2010). Arbeit, Beschäftigung und Arbeitsmarkt aus der Genderperspektive Genderperspektive [Work, employment, and the labour market from a gender perspective]. In F. Böhle, G. G. Voß, \& G. Wachtler (Eds.), Handbuch Arbeitssoziologie [Handbook of the sociology of work] (pp. 671-698). Springer.

Huxel, K., Karakayali, J., Palenga-Möllenbeck, E., Schmidbaur, M., Shinozaki, K., Spies, T., Supik, L., \& Tuider, E. (2020). Postmigrantisch gelesen: Transnationalität, Gender, Care [Read postmigrantically: Transnationality, gender, care]. transcript.

Karakayali, J. (2010). Transnational Haushalten. Biografische Interviews mit care workers aus Osteuropa [Transnational housekeeping. Biographical interviews with care workers from eastern europe]. Springer.

Kemper, A. (2016). Klassismus: Eine Bestandsaufnahme [Classism: A survey]. Friedrich-Ebert-Stiftung Landesbüro Thüringen.

Khalil, S., Lietz, A., \& Mayer, S. J. (2020). Systemrelevant und prekär beschäftigt: Wie Migrant*innen unser Gemeinwesen aufrechterhalten [Systemically relevant and precariously employed: How migrants keep our community going] (DeZIM Research Note No. 3). DeZIM Institut.

Kilkey, M., \& Perrons, D. (2010). Gendered divisions in domestic work time: The rise of the (migrant) handyman phenomenon. Time \& Society, 19(2), 239-264.

Kilkey, M., Perrons, D., \& Plomien, A. (2013). Gender, migration and domestic work: Masculinities, male labour and fathering in the UK and USA. Palgrave Macmillan.

Kivisto, P., \& Faist, T. (2007). Citizenship: Discourse, theory, and transnational prospects. Blackwell.

Kofman, E., \& Raghuram, P. (2015). Gendered migrations and global social reproduction. Palgrave Macmillan.

Kordasiewicz, A. (2016). (U)sługi domowe: Przemiany 
relacji społecznych w płatnej pracy domowej [Domestic services/servants: The transformation of social relations in paid domestic work]. Wydawnictwo Naukowe Uniwersytetu Mikołaja Kopernika.

Krawietz, J. (2014). Pflege grenzüberschreitend organisieren. Eine Studie zur transnationalen Vermittlung von Care-Arbeit [Organising care across borders: A study on the transnational mediation of care work]. Mabuse.

Ledoux, C., Shire, K., \& van Hooren, F. (2021). The dynamics of welfare markets: Private pensions and domestic/care services in europe. Palgrave Macmillan.

Leiber, S., Matuszczyk, K., \& Rossow, V. (2019). Private labor market intermediaries in the europeanized live-in care market between Germany and Poland: A typology. Zeitschrift für Sozialreform, 65(3), 365-392.

Lutz, H. (2008). Vom Weltmarkt in den Privathaushalt: Die neuen Dienstmädchen im Zeitalter der Globalisierung [From the global market to the private household: The new maids in the age of globalisation] (2nd ed.). Budrich.

Mayblin, L., Piekut, A., \& Valentine, G. (2016). "Other" posts in "other" places: Poland through a postcolonial lens? Sociology, 50(1), 60-76.

Mclntosh, P. (1997). White privilege and male privilege: A personal account of coming to see correspondences through work in women's studies. In R. Delgado \& J. Stefancic (Eds.), Critical white studies: Looking behind the mirror (pp. 291-299). Temple University Press.

Mense-Petermann, U. (2020). Theorizing transnational labour markets: A research heuristic based on the new economic sociology. Global Networks, 20(3), 410-433.

Mills, C. W. (1997). The racial contract. Cornell University Press.

Ortiga, Y. Y., Wee, K., \& Yeoh, B. S. A. (2021). Connecting care chains and care diamonds: The elderly care skills regime in Singapore. Global Networks, 21(2), 434-454.

Palenga-Möllenbeck, E. (2016). Unequal fatherhoods: Citizenship, gender, and masculinities in outsourced "male" domestic work. In B. Gullikstad, G. K. Kristensen, \& P. Ringrose (Eds.), Paid migrant domestic labour in a changing Europe (pp. 217-243). Palgrave
Macmillan.

Palenga-Möllenbeck, E. (2021). “Lade Deine Superkräfte wieder auf." Vermittlungs- und Entsendeagenturen und das Konzept der Guten Arbeit in der LiveIn-Betreuung ["Recharge your superpowers." Placement and sending agencies and the concept of decent work in live-in care]. In B. Aulenbacher, $\mathrm{H}$. Lutz, \& K. Schwiter (Eds.), Gute Sorge ohne gute Arbeit? Live-in-Care in Deutschland, Österreich und der Schweiz [Decent care without decent work? Livein care in Germany, Austria and Switzerland] (pp. 106-126). Beltz Juventa.

Plomien, A., \& Schwartz, G. (2020). Labour mobility in transnational Europe: Between depletion, mitigation and citizenship entitlements harm. European Journal of Politics and Gender, 3(2), 237-256.

Safuta, A. (2018). Fifty shades of white: Eastern Europeans' "peripheral whiteness" in the context of domestic services provided by migrant women. Tijdschrift voor Genderstudies, 21(3), 217-231.

Shire, K. (2020). The social order of transnational migration markets. Global Networks, 20(3), 434-453.

Skrivankova, K. (2010). Between decent work and forced labour: Examining the continuum of exploitation. Joseph Rowntree Foundation.

Spivak, G. C. (1988). Can the subaltern speak? In C. Nelson \& L. Grossberg (Eds.), Marxism and the interpretation of culture (pp. 271-313). Macmillan Education.

Terkessidis, M. (2019). Wessen Erinnerung zählt? Koloniale Vergangenheit und Rassismus heute [Whose memory counts? Colonial past and racism today]. Hoffmann und Campe.

Waerness, K. (1984). The rationality of caring. Economic and Industrial Democracy, 5(2), 185-211.

Wetterer, A. (2017). Arbeitsteilung und Geschlechterkonstruktion: "Gender at work" in theoretischer und historischer Perspektive [The division of labour and the construction of gender: "Gender at work" in theoretical and historical perspective]. Herbert von Halem.

Yuval-Davis, N. (2006). Intersectionality and feminist politics. European Journal of Women's Studies, 13(3), 193-209.

Zarycki, T. (2014). Ideologies of Eastness in central and eastern Europe. Routledge.

\section{About the Author}

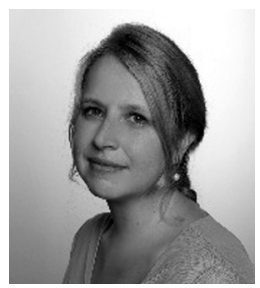

Ewa Palenga-Möllenbeck is a post-doctoral researcher and lecturer at the chair for sociology of inequality at Goethe University Frankfurt and a member of the Cornelia Goethe Centre for Women's and Gender Studies. Her teaching and research interests focus on gender, intersectionality, care, anti-discrimination, mobility, and transnationalism. 